\title{
An Assessment of Health Worker's view on the Current Single Spine Pay Policy. A Case Study on Doctors and Nurses in Greater Accra Region, Ghana
}

\author{
Anthony Kwame Apedzi* \\ Ministry of Health, Ghana \\ *Corresponding author: Anthony Kwame Apedzi, Ministry of Health, Ghana
}

\begin{tabular}{l} 
ARTICLE INFO \\
\hline Received: 㓞 August 12, 2019 \\
Published: August 27, 2019 \\
\hline Citation: Anthony Kwame Apedzi. An \\
Assessment of Health Worker's view \\
on the Current Single Spine Pay Policy. \\
A Case Study on Doctors and Nurses in \\
Greater Accra Region, Ghana. Biomed \\
J Sci \& Tech Res 20(5)-2019. BJSTR. \\
MS.ID.003527.
\end{tabular}

\begin{abstract}
The essence of this study is to provide information on bringing together, analysis of national discourses about how the single spine pay policy influences the work of doctors and nurses. The main objectives of the study were to examine the impact of the policy on public sector doctors and nurses, and to suggest measures that can help to address the difficulties associated with motivation of public sector health workers, among others. Quantitative and Qualitative research methodologies were used in this study with the pragmatist research paradigm. Case study design was used with doctors and professional nurses in Korle Bu Teaching Hospital (tertiary healthcare facility), Greater Accra Regional Hospital (secondary health care facility), Tema General Hospital (secondary healthcare facility), Dangbe East District Hospital, Ada (primary healthcare facility), and Pentecost Hospital, Madina (primary healthcare facility), all in the Greater Accra Region of Ghana. Data were collected through questionnaires, interviews, archival records and personal observations of the researcher. 557 structured questionnaires were distributed out of which 551 were returned. The results of the study show that the Single Spine Pay Policy served as motivation that increased productivity to a certain level and led to efficiency in service delivery in the public health sector. Their concern is that, the enhanced salary is being eroded by the rise inflation. Again, it was revealed that health workers want the enhanced salary to go with, good working condition such as modern equipment, continuous professional development and recognition of effort such as promotion. Finally, the study recommends that there must be other packages that could help health workers give out their best with enough opportunity for career development as well as equipment.
\end{abstract}

\section{Introduction}

This assessment focused on the various views expressed by public sector health workers on the current single spine pay policy. The assessment looked at doctors and nurses in the public health sector in the Greater Accra region, and the way they perceive motivation in their workplaces. The issue of motivation has received increased attention in recent times. Across the globe, the desire to increase productivity has been a major concern for all organizations both in the public and private sectors, great and small alike. Most organizations globally, especially in the public health sector, usually adopt measures that focus on sophisticated technology, equipment, capital and other materials, more often than paying maximum attention to the 'human side of the enterprise', that is, the workforce Abubakr et al. [1]. Doctors and nurses occupy a central position in any health care facility. They heal and care for people, relieve them of their pain and suffering and prevent diseases WHO [2]. "They are the ultimate resource in health because they manage and synchronise all other health resources, including financing, technology, information and infrastructure" Joint Learning Initiative [3].

Therefore, for them to work effectively, they must be motivated and supported. On the contrary, when there is lack of motivation and satisfaction, workers tend to shirk their duties, absent themselves from work, become impolite and are involved in all kinds of negative behaviours, which usually affect the efficacy of health services (Ramasodi). In addition, lack of motivation partly explains why doctors and nurses in most developing countries 
like Ghana, migrate to western countries. Low salaries, poor working environment, absence of opportunities for professional development and promotion on their grade, leave workers dissatisfied, usually pushing them away from their home countries to search for greener pastures elsewhere Bach [4,5]. therefore, noted that, motivation and employee satisfaction are important, if health workers are to be retained and effectively deliver health services in any part of the world. This is an assertion that the researcher believes in. The various salary structures and incentive packages established to address performance problems in the public health sector according to the Ministry of Health MOH [6] are briefly discussed chronologically.

\section{Additional Duty Hours Allowance (ADHA)}

Before 2008, workers of the public health sector were remunerated based on the Ghana Universal Salary Structure (GUSS) together with all public-sector workers. There was no motivation for scarce skills such as doctors and nurses. Public sector doctors and nurse migrated for greener pastures abroad where higher premium was placed on their skills $\mathrm{MOH}$ [6]. There was pressure on already poor health system as the vital human resource migrated for greener pastures. To motivate public sector health workers, an incentive package was designed for them called Additional Duty Hours Allowance (ADHA). The concept of ADHA was to compensate public workers including doctors and nurses who did extra work, after the maximum forty (40) hours a week which is a provision in the labour law MOH [6]. Doctors and nurses had some level of motivation to work for extra hours. But the management of the ADHA was faced with difficulties as many people signed many hours of additional work done in a month, which was very difficult to prove MOH [6]. The Ministry of Health, therefore, established a maximum ceiling on the hours that health workers can do. For instance, the maximum hours that a doctor and a nurse could sign as an overtime, worked, are as follow:

a. Doctors not more than 200 hours per month

b. Nurses not more than 120 hours per month

Another issue was that, pension fund deductions were made only on the base pay and not the ADHA. This was because the latter was an allowance paid on tabletop, according to the Ministry of Health. Health workers had enhanced remuneration that is, the base pay and ADHA. The extra hours of work were recognized but had unattractive pension benefits. Agitations made Government decided to develop a salary structure for health workers called the Health Sector Salary Structure MOH [6].

\section{Health Sector Salary (HSS)}

Health Sector Salary Structure was created for public health sector workers thus taking them from the Ghana Universal Salary Structure (GUSS) in 2006 and taking into consideration the Base Pay and the Additional Duty Hours Allowance according to the Controller and Accountant General, (CAGD). The consolidated salary going through the Controller and Accountant General meant that, the statutory pension fund, which is the Social Security and National Insurance Trust (SSNIT) deduction was made on the enhanced salary. As the public sector health workers were moved from the GUSS to the HSS in 2006, it came with its concomitant challenges. This was because, the employees of various ministries, departments and agencies were not in favour of this move of giving preferential treatment to health workers. This resulted in general agitation by almost all public sector workers, spearheaded by teachers in the country, resulting into many strike actions CAGD [7]. The newly created Health Sector Salary (HSS) structure also did not solve the problem of remuneration of public sector workers in the country. It even gave rise of discomfort between health workers and other public sector workers. Government once again in 2009, decided to adopt another approach in solving salary problems of all workers, and therefore, introduced the current Single Spine Pay Policy Abbey [8].

\section{Single Spine Pay Policy (SSPP)}

Table 1: Category of compensable factors.

\begin{tabular}{|c|c|}
\hline \multicolumn{2}{|c|}{ Category of Compensable Factors } \\
\hline 1) Knowledge and Skill & 2) Responsibility \\
Knowledge & Consequence of Error \\
Learning Experience & Financial Responsibility \\
Judgment & Responsibility for Goods, Tools, \\
Equipment, Software and People & Supervision of Others \\
Work Environment & Contacts \\
Work Environment & 4) Effort \\
Hazards & Dexterity \\
& Physical Effort \\
& Mental Effort \\
\hline
\end{tabular}

This pay policy was established by the Government in 2010 through the Fair Wages and Salary Commission (FWSC). Section 2, of the Fair Wages and Salary Commission Act of 2007, Act 737 entrusts the Commission to ensure equity, transparency and a step by step implementation of Government public service pay policy. FWSC then adopted a scientific approach in determining public sector salary. Job Evaluation and Analysis was performed on all public sector workers. Thirteen (13) compensable factors categorised into four (4) major subgroups were used FWSC [9]. This is shown on Table 1 below. Representatives of various professional bodies of all public sector institutions participated in the Job Evaluation and Analysis, which determined the base pay. Market premium was also added to the base pay as a consolidated allowance for scares skills in the country at a particular time. There was also a provision for conversion difference. Conversion difference, according to the FWSC, is a top-up salary for a person who will receive a lower base pay when the salary is migrated from the HSS to the SSPP. All these point to the fact that, there is a big challenge when it comes to the remuneration of public sector health workers. After migrating 
health workers to the SSPP, the FWSC states that, salary has been enhanced for all public sector health workers. Health workers are expected to give their maximum performance to justify the increment in salaries.

\section{Statement of Research Problem}

The Ghana Universal Salary Structure (GUSS) pay policy was changed to the Health Sector Salary Structure (HSS) in 2006 which was also changed to the Single Spine Pay Policy (SSPP) in 2010. All these changes happened between the periods of 1999 and 2010 Abbey [8]. The FWSC indicates salary levels are commensurate to job levels in the country. But there are more agitations for salaries to be reviewed upwards under the SSPP. Taking doctors and nurses in Greater Accra as case study, this study was focused on the assessment of workers view on the single spine pay policy as a motivational factor.

\section{Objective of The Study}

The purpose of this study was to assess workers view on the single spine pay policy as a motivation. The specific objective was to assess the impact of the SSPP on public sector doctors and nurses.

\section{Research Question}

Using doctors and nurses as case study, this research aimed at addressing the following question:

a. What has been the impact of the SSPP on your work?

b. Has the increase in salary affected service delivery in any way?

\section{Scope of The Study}

The research was limited to doctors and nurses in the public sector within greater Accra region. This is because, they formed over seventy percent (70\%) of the core clinical staff of the general health workers in Greater Accra. The study covered health facilities in Greater Accra Region since there is a concentration of public health workers (doctors and nurses) and to manage cost. The facilities include: Korle Bu Teaching Hospital (tertiary healthcare facility), Greater Accra Reginal Hospital (secondary health care facility), Tema General Hospital (secondary healthcare facility), Dangbe East District Hospital, Ada (primary healthcare facility), and Pentecost (primary health facilities). Again, the headquarters of all the Trade Unions representing public health workers are in Greater Accra. Primary data was collected from doctors and nurses of hospitals and health facilities in Greater Accra region.

\section{The Concept of Motivation}

Many scholars indicate that employee's salary is a motivational factor. The concept of motivation has been defined by many modern age scholars. In looking at views of health workers on a newly introduced salary structure that determines their salaries therefore requires understanding of the concept of motivation by scholars. Motivation is a complex force that causes a person to start and stay working in an institution Dubin [10]. Dubin [10] definition was expressed by some of the participants in the research. Motivation, according to Chang [11], is a vital pillar with regards to human resource management. Motivation refers to the stimulation of employees for increased productivity as well as capabilities Ali [12]. Thus, motivation is something that makes a person initiate an action and causes them to keep doing that act. Motivation can be explained as how a person works with enthusiasm and commitment in exerting his energy to help an organization achieve its goals. Higgins [13], defines it as an intrinsic desire to satisfy a need that is yet to be satisfied. In corroboration with Higgins [13], Bedeian [14] is of the view that, motivation is the will to accomplish something. Gredler et al. [15] broadly understand motivation as the attribute that moves us to do or not to do something.

The impact on productivity is brought to bear, as these forces influence the person's behaviour Jackson [16]. Presumably, this may be the reason why the Government of Ghana measures the performance of public health workers after investing in motivational packages for workers. A myriad of theories on human needs provides the basis for motivation. However, human resource and line managers are unable to create reward packages for their employees (The Chartered institute of Personnel and Development (CIPD) Reward Survey, 2005). According to Guest et al. [17], the CIPD survey provides the basis for the assertion that, managers fail to motivate and enhance the performance of their employees. The perception that workers leave managers but not organizations seems to suggest that, an organization is bound to collapse for retaining managers who have lost touch with their role in motivating employees and effectively enhancing their performance. In addition, motivation can be grouped under subsidies, rewards and basic level motivation Huang [18]. Subsidies come in the form of payments made for transportation, rent, overtime, benefits for relatives and allowances. The basic level consists of salaries and other benefits whereas rewards consist of end of year reward, performance reward, merit award and many others.

The public-sector health workers in Ghana crave to have these reward systems as some are lacking. The Fair Wages and salary Commission has created categories of allowances to meet the increasing demands of works in this direction. Most of the arguments have been centred on the base pay alone as reward. In the view of Hughes et al. [19] managers, in the past, used to develop their motivation system where compensations were used as a measure to reward and punish employees in accordance with their behaviour. They added that, non-management factors such as the values of employees and their level of awareness of equity should be given much attention, especially in recent times. It is their belief that this will make organizations attractive and also help reduce employee turnover whiles meeting organizational goals. It must be emphasized that motivation is just an exchange for employee services but can serve as a tool used by managers to influence the behaviour of employees Chu [20]. It is therefore imperative for 
public sector organizations to ensure that public sector workers especially health workers are highly motivated and compensated due to the sensitivity of their services. Robbins [21] suggests that, motivation system is centred on three main factors, that is, job-based, performance-based and skill-based pays. A thorough description of these factors is provided below:

\section{Job-Based Pay}

This refers to the salary given to an employee for the job done in an organization Robbins [21]. The decision on the relative value of a job-based pay is made by organizations. The bases for designing the pay include job attributes, job difficulty, and internal equity. Theoretically, the job-based pay is based on the equity theory related to organizational behaviour. As stated by Robbins [21], the equity theory indicates that employees will strive to do away with any inequity after comparing their input and return with that of their colleague employees.

\section{Skill-Based Pay}

This is based on the skills of the employees. Robbins [21] terms this as knowledge-based pay. Essentially, it means that employees receive different pay based on their level of education, skills, as well as capabilities. This clearly seen in the health sector as highly skilled staff as doctors occupy high level on the pay structure.

\section{Performance-Based Pay}

This motivation system puts into consideration, equity and individual unique needs, to adequately reward workers for the work they have done. In as much as this framework tends to add extra cost to the organizations, the benefits it offers cannot be overemphasized. When an organization makes, worker's needs a priority, the workers become motivated to work harder and become committed to their organizations. This strengthens the bond between managers and workers Robbins [21].

\section{The Single Spine Salary Structure}

Price Water House Associate has done a comprehensive study on salary administration in 1997 and recommended fairness across board. The Single Spine Salary structure (SSSS) which seeks to apply fairness in salary administration, is a comprehensive pay policy that has been designed for workers in the public sector (Abbey 2010). The main purpose of the policy is to ensure equity and sustainability as far as remuneration is concerned. The policy also covers all workers in the public sector stipulated under Article 190 of the 1992 constitution who are placed in a unified salary structure. This includes those in the Judicial Service, Civil Service, the Audit Service, Ghana Education Service, the Ghana Health Service, the Parliamentary Service, the National Fire Service, the Customs, Exercise and Preventive Service, the Internal Revenue Service, the Local Government Service, the Police Service, and the Prisons Service. Workers in public corporations other than those set up as commercial ventures, public services established by the constitution and all other public services as Parliament may by law prescribed are also included in the SSSS Abbey [8].

Those excluded from the structure are the military and public officials covered by Article 71 of the 1992 Constitution of Ghana. The Article 71 office holders include the President, the Vice President, the Chairman and Members of Council of State, Ministers of State and their Deputies, the Speaker and Deputy Speakers and Members of Parliament, the Chief Justice and other justices of the Superior Court of Judicature, the Chairman and Deputy Chairman of the Electoral Commission and others. The Single Spine Salary Structure (SSSS) replaces the Ghana Universal Salary Structure (GUSS) and other forms of pay structure within the various public sector institutions in order to restore equity and transparency in public service pay administration. Unlike the GUSS, which was a 22-level salary structure, the SSSS is a 25-level structure. The SSSS also has a common base pay and common relativity across all the levels compared to the GUSS, which had variable base pay and relativities across levels. The base pay is the minimum pay on the SSSS, while the pay-point relativity is the percentage differentials between successive pay points Abbey [8]. Under the Single Spine Pay Policy (SSPP), jobs within the same job value range are paid within the same pay range, in accordance with the principle of 'equal pay for work of equal value'. The value of the public-sector jobs was assessed through job evaluation (JE) exercise. The process of the JE exercise involved evaluation of jobs descriptions and specifications for each job and the summing up of the evaluation points for each job to determine the 'job worth'. Four common factor groupings, including knowledge and skills, responsibility, effort and work conditions were used for the analysis and the evaluation. The result of the JE exercise provided the basis for placement of public service jobs onto the SSSS.

\section{Aims and Objectives of the Single Spine Pay Policy (SSPP)}

The SSPP emphasizes equal pay for work of equal value and aims at motivating public service workers to improve service delivery and productivity. The ultimate goal of the policy is to ensure equity, fairness and transparency in the public service salary administration as well as enhance performance and productivity (fairwages.gov.gh). The specific objectives are to:

a. Place all public-sector employees on one pay structure and ensure all jobs within same job value range are paid within same pay range - equity

b. Enable government to manage the wage bill more efficiently and ensure compliance and ease of monitoring pay structures of self-accounting institutions

c. Minimize industrial-relation tensions related to low pay and distortions across the public service and to link pay to productivity 
Stages in the Implementation of the Single Spine Pay Policy (SSPP)

The SSPP according to Abbey [8] had key implementation stages and these include:

a. Job analysis and evaluation as well as design of a grading structure based on the results of the job evaluation.

b. Placement of jobs on the grading structure and determination of the base pay and relativity through negotiations as well as design of the SSSS

c. Placement of the individual jobholders on the SSSS, standardization of the allowances and negotiation of other conditions of service between Fair Wages and Salaries Commission (FWSC) and unions/associations in the nineservice classification

Finally, there was determination of market premiums and inducements, development of public sector-wide performance system, monitoring and ensuring compliance

\section{Market Premium}

A "Market Premium" is defined by the Government White Paper on the Single Spine Pay Policy (SSPP) released in 2009 as "monetary incentive paid to attract and retain critical skills in short supply within the economy. The premium is to bring the salaries of skills in short supply to be close or equal to the actual market value of such skills. The rationale was to enable the public services compete favourably for such skills with the private sector". The market premium is essentially an absolute amount paid only to employees with critical skills in short supply. It is paid to attract and retain critical skills in short supply within the economy. It was envisaged that the Market Premium was to be used as a tool to attract and retain critical skills in short supply in the public service and thus make available the mix of skills needed for public service delivery. The scarce skill in the public service is one that is in short supply relative to the demand for it in the labour market within a defined period as determined by Government Abbey [8].

\section{Research Methodology}

\section{Research Design}

The study used a mixed method made up of quantitative and qualitative survey through the use of questionnaires and interviews as well as focus group discussions (FDG). The researcher chose this approach because findings from both methods complemented each other and adequately achieve the research objectives. The outcome of the quantitative methods assisted in making generalizations about the study population, while that of interviews and FGDs elicited in-depth explanations on motivation and retention of doctors and nurses in the public health sector in Ghana. The case study location was the public health sector in the Greater Accra Region. Respondents were from the various level of health facilities in Greater Accra. These are the major Tertiary, Secondary and Primary healthcare facilities in Greater Accra. Respondents were from Korle Bu Teaching Hospital (Tertiary health facility), Greater Accra Regional Hospital (formally Ridge Hospital (secondary health facility), Tema General Hospital (secondary Health facility), Dangbe East District Hospital, Ada, (District Hospital), Pentecost Hospital (Primary Healthcare facility). According to the Ministry of Health (2015), doctors and professional nurses (state registered nurses) in the Greater Accra Region are five thousand, four hundred and twenty-six (5426) (Figure 1).

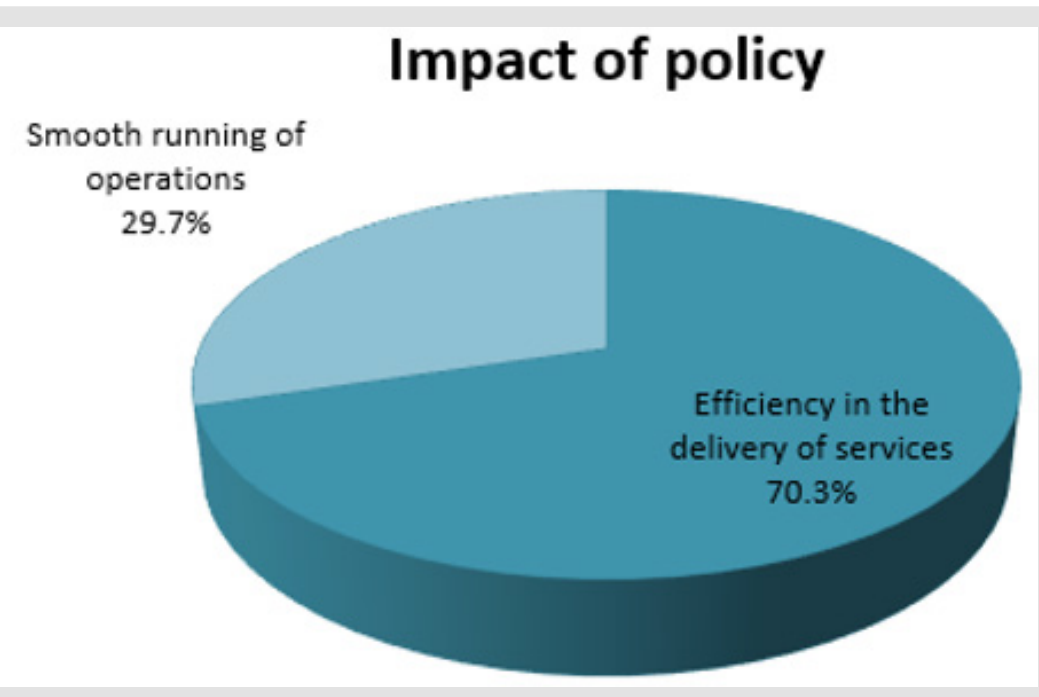

Figure 1: Impact of SSPP on Service Provision (Source: Field Work, 2016).

\section{Sample Size}

Doctors and Professional Nurses were targeted for this study mainly because they are the front leaders in the health care delivery. Again, they have more contact hours with patients clinically. Any strike action of any of these professional groups paralyse the health system from day one. They also have a very vociferous trade unions in the health sector, that is, the Ghana Medical Association and the Ghana Registered Nurses Association. The population of doctors 
and nurses in the Greater Accra Region as highlighted above, is five thousand, four hundred and twenty-six $(5,426)$ (Figure 2). A sample size of five hundred and fifty-one (551) respondents, which represents more than $10 \%$ of this population of doctors and professional nurses, was chosen from public health institutions in the Greater Accra for this study. The break down is, 131 doctors and 420 nurses participated in the study. Also, 150 patients were selected from the hospitals to participate in the study. Due to the large population size and resource constraints, the study adopted purposive and random sampling technique for doctors and nurses. Purposive sampling technique was employed to select 131 doctors for the study. Random sampling was also used to select the 420 nurses. The $10 \%$ of population size, according to Mason et al. [22], can be used to make generalization. The sample size was determined using the formula: is the population and is the sample.

$$
\frac{\sigma}{\eta}=\frac{5426}{10}=542.6
$$

\section{How the policy contributes positively to response to work}

now the policy contributes positively to res ponse to work

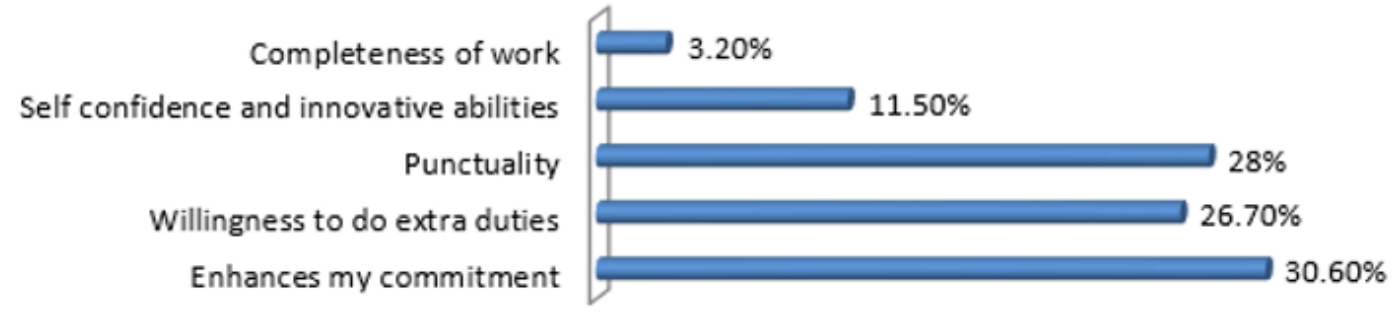

Figure 2: Contribution of the Pay Policy in the response to duty.

\section{Discussion}

The objectives of the study formed the foundation for the analysis of the data. The study seeks to achieve certain objectives and answer some critical research questions, which were generated from the review of literature. It is very vital that the results that were obtained from the field work are juxtaposed against the findings of other scholars in the extant or existing literature.

\section{Impact of Single Spine Pay Policy (SSPP) On Service} Provision

Table 2: Category of compensable factors.

\begin{tabular}{|c|c|}
\hline Category & Greater Accra \\
\hline Doctors & 1288 \\
\hline Professional Nurses & 4138 \\
\hline Total & 5426 \\
\hline
\end{tabular}

Concerning the impact of the SSPP on service provision, 345 of the respondents constituting $62.6 \%$ indicated that efficiency in service delivery is a key impact the SSPP on health sector. This included the early attendance of staff to work and the commitment to duty on the job. Respondents also added that serving patients is also done with joy due to the high sense of responsibility. Kreitner et al. [23] indicate that financial increment serves as an impetus and awakens the strength in the workforce which makes them to perform more efficiently. The condition before the implementation of the SSPP according to some respondents, was the issue of lack of financial motivation and the poor conditions of service [24]. This demotivated most of the staff in executing their responsibilities.
Again, 146 respondents representing 26.5\% were of the view that the Single Spine Pay Policy guarantees the smooth running of the operations as far as health service delivery is concerned. This is represented in the Table 2 below.

\section{Contribution of The Pay Policy in The Response to Duty}

With regard to the contribution of the Single Spine Pay Policy in the response to duty, 163 respondents representing 29.6\% were of the view that, it has enhanced commitment to work while 142 respondents constituting $25.8 \%$ indicated that, it has created the zeal and willingness to do extra duties. In addition, punctuality, self-confidence and innovative ability recorded $28.0 \%, 11.5 \%$ and $3.2 \%$ respectively. An independent t-test was conducted to examine whether there are differences in the satisfaction with current remuneration across job categories. The test revealed a significant difference ( $\mathrm{p}<0.000, \mathrm{~T}=-3.667$ (549), hence the satisfaction with current remuneration varies across job categories. It was observed that, even though both doctors and nurses are not satisfied with their current salaries, doctors $(M=1.55, S D=0.51)$ are the least satisfied, as compared to the nurses ( $M=1.95, \mathrm{SD}=0.47)$ [25-27]. The researcher was interested in ascertaining the general perceptions of doctors and nurses on the level of motivation of health workers. The study delved into perceptions of doctors and nurses on how well they are motivated in order for them to give in their best in the process of discharging their duties.

A 5-point Likert-scale was therefore used to measure the degree of agreement or disagreement on the statement, "Public health workers are highly motivated". For this purpose, an independent 
t-test was conducted to examine the differences between the doctors and nurses on this variable. The test revealed a significant difference $(\mathrm{p}$-value $=0.002, \mathrm{~T}=3.562(19.494))$ with regards to perceptions about motivation in the health sector. Doctors $(\mathrm{M}=$ 2.0500, $S D=0.887$ ) were more supportive of the view that health workers are highly motivated, as compare to nurses $(M=1.339$, $\mathrm{SD}=0.519$ ). The analysis is summarized in the Table 3 below. A One-way ANOVA was used to explore the differences in perception among doctors and nurses on level of motivation. It can be observed that there is a significant difference in the perception of doctors and nurses $F(1,551)=0.733, p=0.002$, one tailed). The effect size is however small (0.02). With a standard deviation and a mean score of 2.96 and 24.91 respectively, the nurses were identified with the opinion that the criteria employed in the promotion of health workers are not fair. This is in contrast with the views of the doctors $(M=25.50, S D=4.19)$, who are relatively affirmative of this view. In order to test the relationship between staff category and desire to work overtime, the Pearson Product Moment Coefficient was used. The results from the Table 4 above indicates there is no significant relation between category of staff (Doctors and Nurses) and desire to work overtime $(\mathrm{r}=-.069, \mathrm{~N}=551, \mathrm{p}=.106$, two tailed) (Tables 5-8).

Table 3: Sample size.

\begin{tabular}{|c|c|}
\hline Respondents & Number \\
\hline Doctors & 131 \\
\hline Nurses & 420 \\
\hline TOTAL & $\mathbf{5 5 1}$ \\
\hline
\end{tabular}

Table 4: Impact of Single Spine Pay Policy (SSPP) on Service Provision.

\begin{tabular}{|c|c|c|c|c|c|}
\hline $\begin{array}{c}\text { What in Your View } \\
\text { Is the Impact of the } \\
\text { Policy on Service } \\
\text { Provision }\end{array}$ & & & & \\
\hline & & Frequency & Percent & Valid Percent & Cumulative Percent \\
\hline Valid & $\begin{array}{c}\text { Efficiency in the } \\
\text { delivery of services }\end{array}$ & 345 & 62.6 & 70.3 & 70.3 \\
\hline & $\begin{array}{c}\text { Smooth running of } \\
\text { operations }\end{array}$ & 146 & 26.5 & 29.7 & 100 \\
\hline Missing & Total & 491 & 89.1 & 100 & \\
\hline Total & NR & 60 & 10.9 & & \\
\hline
\end{tabular}

Table 5: Contribution of the policy in the response to duty.

\begin{tabular}{|c|c|c|c|c|c|}
\hline $\begin{array}{l}\text { How Has the } \\
\text { SSPP contributed } \\
\text { positively in your } \\
\text { response to duty }\end{array}$ & & & & & \\
\hline & & Frequency & Percent & Valid Percent & Cumulative Percent \\
\hline \multirow[t]{6}{*}{ Valid } & $\begin{array}{l}\text { Enhanced my } \\
\text { commitment to work }\end{array}$ & 163 & 29.6 & 30.6 & 30.6 \\
\hline & $\begin{array}{l}\text { willingness to do extra } \\
\text { duties }\end{array}$ & 142 & 25.8 & 26.7 & 57.3 \\
\hline & Punctuality & 149 & 27 & 28 & 85.3 \\
\hline & $\begin{array}{l}\text { self-confidence and } \\
\text { innovative ability }\end{array}$ & 61 & 11.1 & 11.5 & 96.8 \\
\hline & completeness of work & 17 & 3.1 & 3.2 & 100 \\
\hline & Total & 532 & 96.6 & 100 & \\
\hline Missing & NR & 19 & 3.4 & & \\
\hline Total & & 551 & 100 & & \\
\hline
\end{tabular}

Table 6: Independent t-test on job category and satisfaction with remuneration.

\begin{tabular}{|c|c|c|c|}
\hline Job category & M (SD) & T (DF) & P<0.005 \\
\hline Doctors & $1.55(0.51)$ & $-3.667(549)$ & 0 \\
\hline Nurses & $1.95(0.47)$ & & \\
\hline
\end{tabular}

Table 7: Summary of F test, Means, SD of Staff Category and perception on health workers' level of motivation.

\begin{tabular}{|c|c|c|c|c|c|c|}
\hline Category & N & Mean & SD & df & F & p \\
\hline Doctors & 131 & 25.50 & 4.19 & 1 & 0.733 & 0.002 \\
\hline Nurses & 420 & 24.91 & 2.91 & & & \\
\hline
\end{tabular}


Table 8: Summary of Pearson r Test, Means, SD of Scores of Health Workers and the desire to work overtime.

\begin{tabular}{|c|c|c|c|c|}
\hline Variable & N & Mean & SD & r \\
\hline Desire to Work Overtime & 551 & 33.74 & 2.97 & -0.069 \\
\hline Category of Staff & 551 & 22.92 & 0.106 & \\
\hline
\end{tabular}

\section{Conclusion}

The study was conducted to assess workers view about the new pay policy, that is, the Single Spine Pay Policy as a motivation for performance. Public sector doctors and nurses in the Greater Accra Region, Ghana, were used as a case study. The essence of this study was to provide information on, bringing together analysis of national discourses about how the single spine pay policy influences the work of doctors and nurses. The main objective of the study was to examine the impact of the policy on public sector doctors and nurses. Quantitative and Qualitative research methodologies were used in the study with the pragmatism as the research philosophy. Case study design was used with doctors and professional nurses in the Greater Accra Region of Ghana. Data were collected through questionnaires, in-depth interviews, archival records and personal observations of the researcher. In the end, the results of the study revealed that, the Single Spine Pay Policy served as motivation that increased productivity to a certain level and led to some level of efficiency in service delivery, in the public health sector. But the enhanced salary alone cannot be seen as motivation, not to mention the ever-increasing inflation which erodes the gains in the enhanced salary. Good working environment with adequate modern equipment with retraining on the job, were seen to be some key motivational factors that are needed.

\section{Limitations of The Study}

The study was diligently carried out but not without limitations. Key among the limitations was data administration collection. This is because the researchers had to collect more data to be able to meet the required sample of 551. Also, time was another limitation where respondents were too busy to give audience to the researchers, hence the inconvenience of going back to them on several occasions.

\section{Interest}

The author declare that they are not in any professional group that have interest in the research.

\section{References}

1. Abubakr M, Nawal A (2009) Surviving Through the Global Downturn: Employee Motivation and Performance in Healthcare Industry. The Open Business Journal 2: 86-94.

2. (2006) World Health Organisation The Health Care Workforce in Europe, Learning from Experience: European Observatory on Health Systems and Policies.

3. (2004) Joint Learning Initiative p. 26.

4. Bach S (2003) International Migration of Health Workers: Labour and Social Issues. Sectorial Activities Programme Working Paper. International Labour Office Geneva.

5. Peters M, Steinhardt B (2010) Injustice in Social Exchange. Advances in Experimental Psychology. Berkowitz L (Eds.). Academic Press, New
York, USA.

6. (2007) Ministry of Health Assessing the Additional Duty Hours Allowance Scheme Final Report.

7. (2014) Controller and Accountant General Bulletin.

8. Abbey K (2010) The Dilemma of Macroeconomic Policymaking: CEPA News.

9. (2007) Fair Wages and Salary Commission Act, Act 737, Section 2.

10. Dubin J (2002) Leadership: Research findings, Practice and Skills, Houghton Mifflin Company, New York, USA.

11. Chang G (2006) Ability as a Moderator of the Relationship between Job Attitudes and Job Performance Personnel Psychology 19: 153-164.

12. Ali A (2009) The Role of Leadership in Human Resource Management a Comparative Study of Specific Public and Private Sectors in Pakistan. Journal of Management and Social Sciences 5(2): 180-194.

13. Higgins A (2004) Work Motivation, Job Satisfaction and Organisational Commitment of Library Personnel in Academic and Research Library in Oyo State, Nigeria. Library Philosophy and Practice 1-16.

14. Bedeian H (2009) Educational Leadership: Personal growth for professional development.

Sage Publication, London.

15. Gredler H, Broussard P, Garrison T (2004) Motivating the academically unmotivated: A critical issue for the 21st century. Review of Educational Research 70(2): 151-179.

16. Jackson T (2000) Handling Grievances. London: Chartered Institute of Personnel Development.

17. (2005) Guest M, Conway Y Organisational Behaviour: Managing People and Organisations, (11 $1^{\text {th }}$ Edn). South-Western Cengage Learning, Australia.

18. Huang C (2007) Human Resource Policies and Strategies for Health Sector 2002-2006.

19. (1989) Hughes K, Wright G Fundamentals of Management. London: McGraw Hill Companies. Harper, Collins Publishers, New York, USA.

20. Chu K (2005) Industrial / Organizational Psychology: An Applied Approach. ( $5^{\text {th }}$ Edn). Thomas Learning Inc, Belmont CA.

21. Robbins SP (1992) Failing to find fit in strategic human resource management: Theoretical and empirical problems. Wright P, Dyer L, Boudreau J, Milkovich G (Eds.). Research in Personnel and Human Resource Management, JAI Press, Greenwich CT, p. 53-74.

22. Mason LJ, Mann M (1983) MacMillan Student Encyclopaedia of Sociology. Mac Millan, London.

23. Kreitner J, Kinicki M (2001) Introduction to Organisational Behaviour, ( $4^{\text {th }}$ Edn). Pearson Education, Inc, New York, USA.

24. Agyepong AI, Anafi P, Asiamah E, Ansah KE, Ashong AD, et al. (2004) Internal Customer Satisfaction and Motivation in the Public Sector in Ghana, Health Planning Management 19(4): 391-366.

25. Buford G, Bedeian M, Linder A (2005) The Role of Institutionalization in Cultural Persistence. American Journal of Sociology 42(5): 726-742.

26. Kreitner J (1995) From a Clinical Engineering Perspective: Understanding Motivation and Employee Satisfaction. Clinical Engineering Management 38(4): 283-287.

27. (1997) Price Waterhouse Associates, Ghana: Technical Assistance to Facilitate the Development and Implementation of Medium to LongTerm Public-Sector Salaries and Wages Policy, June Monthly Status Report. 
ISSN: 2574-1241

DOI: 10.26717/BJSTR.2019.20.003527

Anthony Kwame Apedzi. Biomed J Sci \& Tech Res

(C) (P) This work is licensed under Creative

Submission Link: https://biomedres.us/submit-manuscript.php

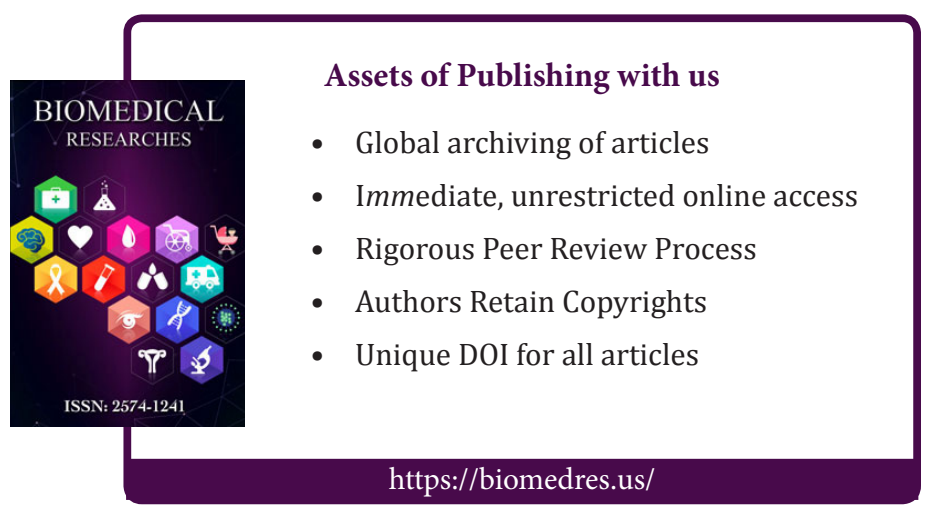

